\title{
Overview of the gaps, challenges and prospects of red palm weevil management
}

\author{
Jose Romeno Faleiro ${ }^{1}$, Michel Ferry ${ }^{2}$, Thaer Yaseen ${ }^{3}$ and Shoki Al-Dobai ${ }^{4}$ \\ (1) FAO, Goa-India, email: jrfaleiro@yahoo.co.in; (2) Phoenix Research Station, Spain, email: ferry.palm@gmail.com; \\ (3) FAO-RNE, Cairo, Egypt, email: thaer.yaseen@fao.org; (4) FAO-Rome, Italy, email: shoki.aldobai@ fao.org
}

\begin{abstract}
Faleiro, J.R., M. Ferry, Th. Yaseen and S. Al-Dobai. 2019. Overview of the gaps, challenges and prospects of red palm weevil management. Arab Journal of Plant Protection, 37(2): 170-177.

The Red Palm Weevil (RPW) Rhynchophorus ferrugineus Olivier has emerged as a key pest of palms in diverse agro-ecosystems worldwide. RPW has its home in South and South-East Asia where it has been a major pest of coconut. Ever since it was reported on date palm in the Middle East during the mid-1980s, it has spread rapidly mainly through infested planting material. Recent reports of RPW invasion suggest that the pest is gaining foot hold in the Caucasian region where it is detected from Sochi in Russia and Abkhazia in the republic of Georgia and also from East Africa in Djibouti. The current RPW IPM programmes, based on pheromone/bait trapping among other techniques have been implemented with limited success. Gaps and challenges in almost all the components of the strategy, particularly with regard to early detection of the pest, developing and implementing phytosanitary measures, lack of farmer participation in the programmes and scarcity of data on socio-economic issues among several other factors have made RPW control and eradication extremely difficult. On the positive side, the pest has been eradicated in the Canary Islands and is approaching eradication in Mauritania. Eradication has also been obtained in various oasis in Oman but new introductions of infested palms have ruined these successes. The Food and Agriculture Organization of the UN during the Scientific and High Level Meeting on the Management of RPW in March, 2017 called for the urgent need to combat RPW by collaborative efforts and commitments at the country, regional and global levels to stop the spread of this devastating pest and formulated a framework strategy for eradication of RPW which aims to support efforts/programs of countries to stop its spread, to achieve a strong decline and if possible its eradication. This has led to the 'FAO Programme on RPW Eradication in the NENA Region' to intensify governance, monitoring, scientific research, capacity building and coordination. The program fosters the ongoing research on the applicable approaches of biological control and innovative detection and control methods. Furthermore, the 'FAO Global RPW management platform' aims mainly at monitoring the pest using mobile apps and GIS based techniques. This presentation highlights the gaps and challenges in the current RPWIPM strategy with prospects for improving each component of the RPW-IPM program, based on a much better knowledge on the socioeconomic situation and the participation of the farmers and other stakeholders.
\end{abstract}

Keywords: Rhynchophorus ferrugineus, area-wide management, regional, global, constraints, vision.

\section{Introduction}

The Red Palm Weevil (RPW) Rhynchophorus ferrugineus Olivier (Coleoptera: Curculionidae) is a key pest of palms that has expanded its geographical and host range during the last three decades, ever since it gained foot hold on date palm Phoenix dactylifera $\mathrm{L}$. in the Middle-East during the mid19980s (Faleiro, 2006; Giblin-Davis et al., 2013; Gomez and Ferry, 2002). Rhynchophorus palm weevils threaten agricultural areas and natural landscapes (Milosavljević et al., 2018) and RPW poses a major threat to palm species in diverse agro-ecosystems worldwide. Recently the Caucuses (Sochi in Russia and Abkhazia in Georgia-Faleiro, 2018) and East Africa (Djibouti: Personal communication from Mr. Yusuf Duhur on 16 June, 2018) have detected RPW on the Canary palm and date palm, respectively. The pest poses a major challenge to date palm farming in the Near East and North Africa (NENA) region which accounts for nearly 90 $\%$ of the global date production, threatening livelihood security of rural farming communities. RPW is known to move within national, regional and international boundaries mainly through infested planting material transported for farming and landscape gardening. This calls for the urgent development of quarantine protocols and strict implementation of phytosanitary measures, to restrict the spread of RPW and also to sustain control levels where the pest has been successfully controlled (Faleiro et al., 2012; Hoddle et al., 2013). Besides phytosanitary measures, the key to the success of any RPW control strategy is the early detection and treatment of infested palms. Currently detection of infested palms is done manually by visual inspections. A recent study (Pugliese et al., 2018) on the use of several early detection devices based on thermal imaging, digital camera, tree radar unit and densitometer, concluded that thermal cameras and densitometers hold promise for future RPW detection where detection accuracy levels were nearly $90 \%$.

Keeping in view the seriousness of the problem, the Food and Agriculture Organization (FAO) of the United Nations along with the International Centre for Advanced Mediterranean Agronomic Studies (CIHEAM) organized a Scientific Consultation and High Level Meeting during March, 2017 wherein a multi-discipline and multi-regional strategy to combat RPW was proposed (http://www.fao.org/3/a-ms665e.pdf). Although, many control means based on conventional and innovative technologies are today in place, FAO attributes the failure to manage RPW in most of the countries to the lack of awareness and systematic and coordinated control actions or management strategies that involve all stakeholders, which is related to inadequate human and financial resources available to combat the pest. 
In general, the failure to control RPW is often not due to the lack of technology but is largely related to socioeconomic and operational issues (Figure 1). Very few quantitative data are available on the economic and social impacts of the RPW, at the local or at the national level. To establish such data constitutes an urgent priority. It will allow first to justify by an analysis the cost/benefit ratio to control this pest and, secondly, to identify the weaknesses of the present control programmes and to elaborate socio-economic solutions (Abdedaiem et al., 2017). Eradication of the pest conceived as a long-term goal is a strategic mistake that is not sustainable. Hence, upon recording the pest, it is essential to quickly provide the necessary resources (human and material) for the control and eradication of RPW in an adequate and timely manner for the rapid control of the pest (Ferry et al., 2018).

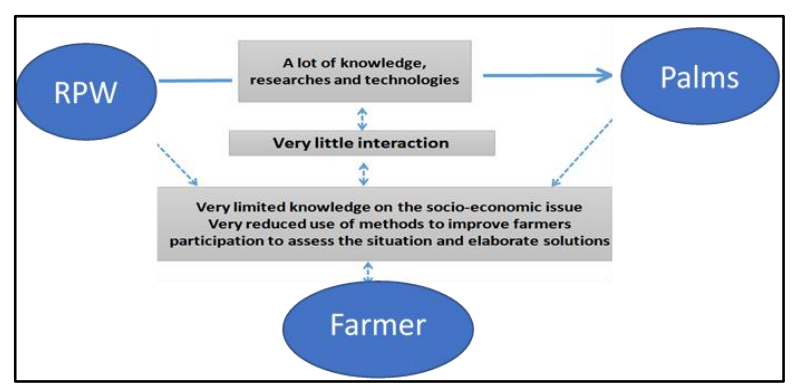

Figure 1. Socio-economic data at the local and national level on the impact of the RPW (Source: Ferry et al., 2018).

The current RPW IPM strategy was first tested in Saudi Arabia in date palm and proposed by Abraham et al. (1998). This strategy has evolved over the years (Aldobai and Ferry, 2017) and as illustrated in figures 2 and 3 is based on several components including detection of infested palm, pheromone trapping, chemical treatments, removal of severely infested palms, phytosanitary measures among other techniques; which has been implemented with limited success in several countries. The gaps and challenges in almost all the components of the strategy, particularly with regard to early detection of RPW, developing and implementing phytosanitary measures, lack of farmer participation in the programmes and scarcity of data on socio-economic issues, among several other factors, has made control and eradication of this lethal pest extremely difficult. On the positive side, the pest has been eradicated in the Canary Islands and is approaching eradication in Mauritania (Fajardo et al., 2017a and http://propalmes83.com/index.php/actualites2/105-enmauritanie-nette-regression-du-charancon).

A recent report on Rhynchophorus palm weevils suggests that enhanced consideration should be given to exclusionary quarantine regulations, invasion monitoring, and eradication to prevent establishment and spread of Rhynchophorus spp. Furthermore, management strategies in the future need breakthroughs in surveillance, genetic modification of palm hosts, and new association of biological control (Milosavljević et al., 2018). During the Rome meeting in March 2017 the RPW-IPM strategy was deliberated thoroughly (http://www.fao.org/3/ams665e.pdf). The following is a summary of the major gaps and challenges in the current RPW-IPM strategy with prospects for improving each component of the RPW-IPM program (Table 1).

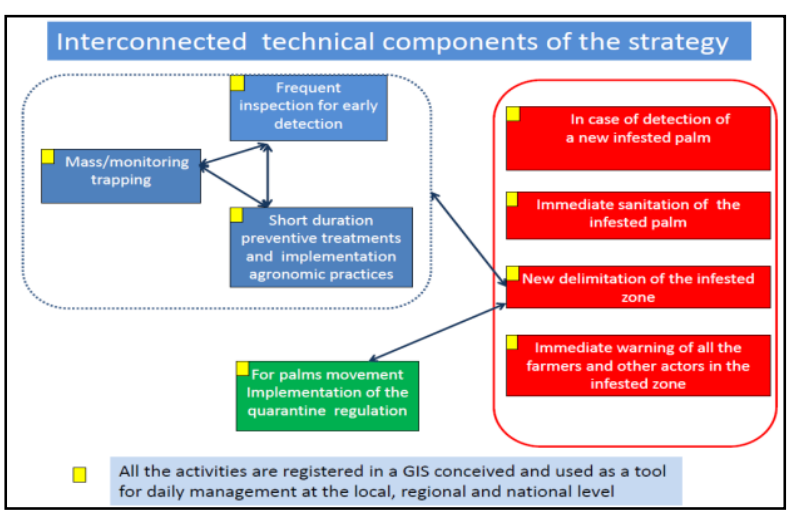

Figure 2. Interconnected components of the RPW-IPM strategy (Source: M. Ferry. http://www.fao.org/3/a-ms665e.pdf)

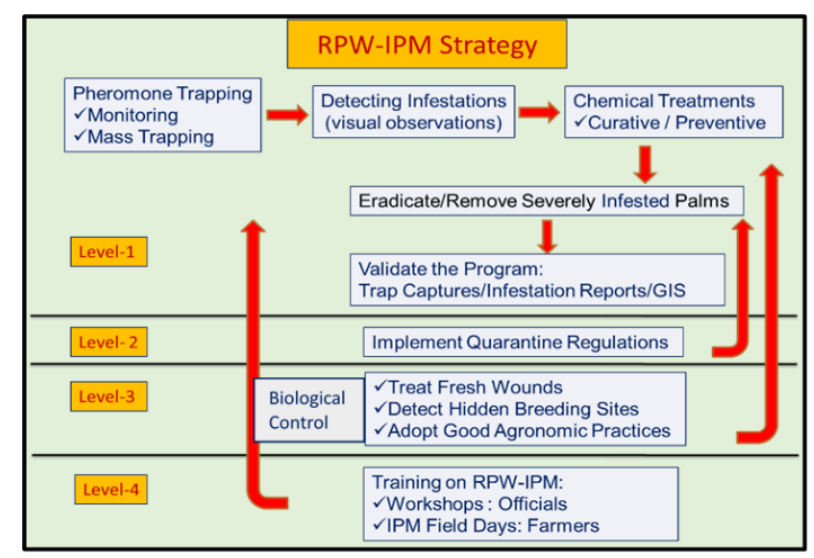

Figure 3. Operational details of the RPW-IPM strategy implemented at different levels (Updated from http://www.fao.org/3/a-ms665e.pdf)

\section{Farmer Participation in RPW Management}

Farmer participation in the RPW control programs in several Middle East countries is almost non-existing. Previous research suggests that for the efficient management of mobile insect pests in area-wide operations, farmer participation and cooperation is vital for the program to succeed ( $\mathrm{Yu}$ and Leung, 2006). The challenge is therefore to enhance the involvement by farmers in the control of RPW in their farms and keep state support/participation in the program to the bare minimum. In this context it is essential to generate data on socio-economic aspects of RPW control through pilot studies on the participation by farmers in the RPW control program and also build capacities of farmers/ national staff on RPW control national/regional initiatives (FAO trust fund for NENA Region) so as to enhance farmer participation in the control of the pest through Farmer Field Schools (Abdedaiem et al., 2017; Aldobai and Ferry, 2017). It is pertinent to mention that besides building capacities of all stakeholders, increased awareness and extension campaigns on RPW management is essential in all the NENA countries to enhance farmer participation in the control program. 
Table 1. Major gaps, challenges and prospects of the RPW-IPM strategy

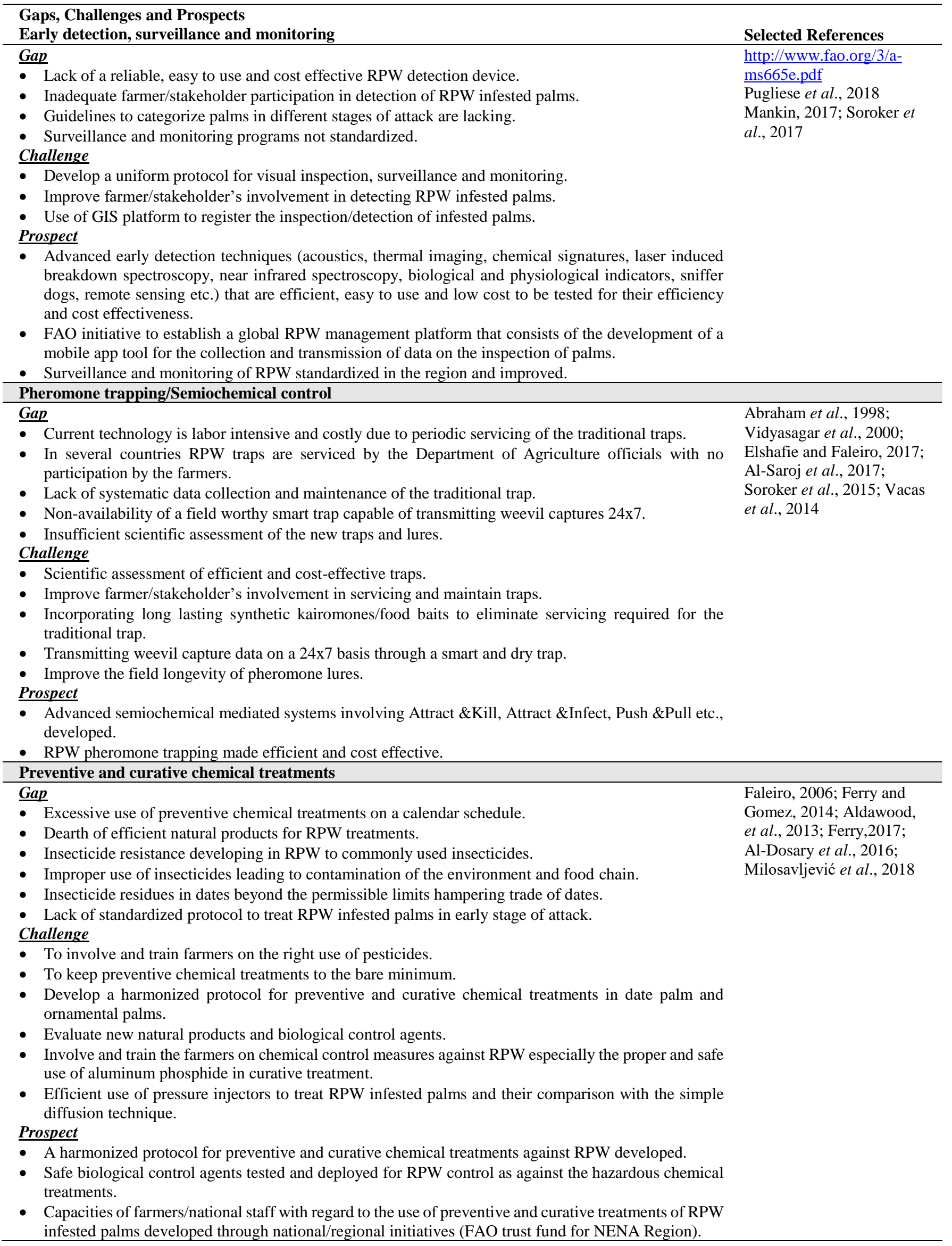


Table 1. Cont.....

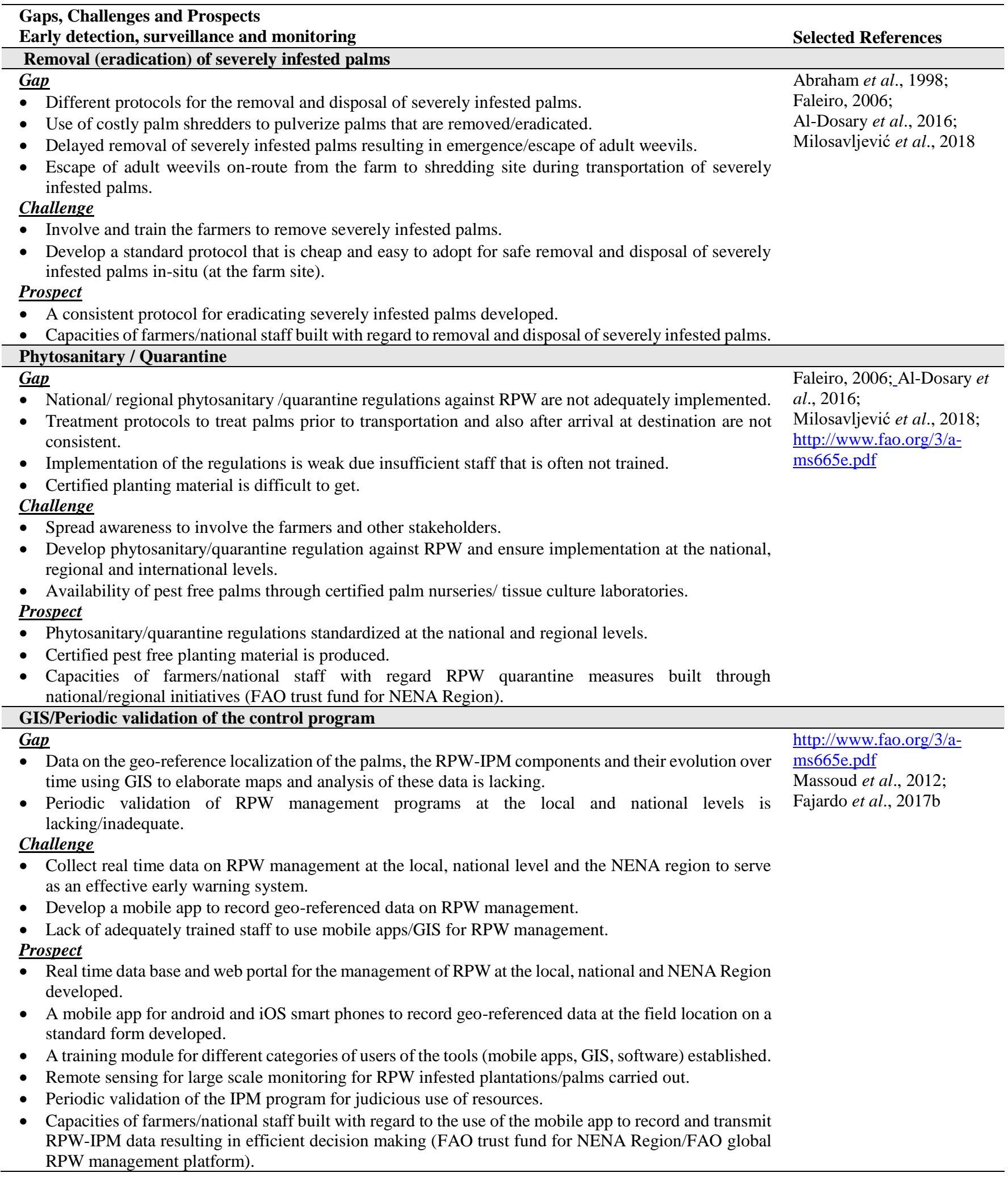


Table 1. Cont....

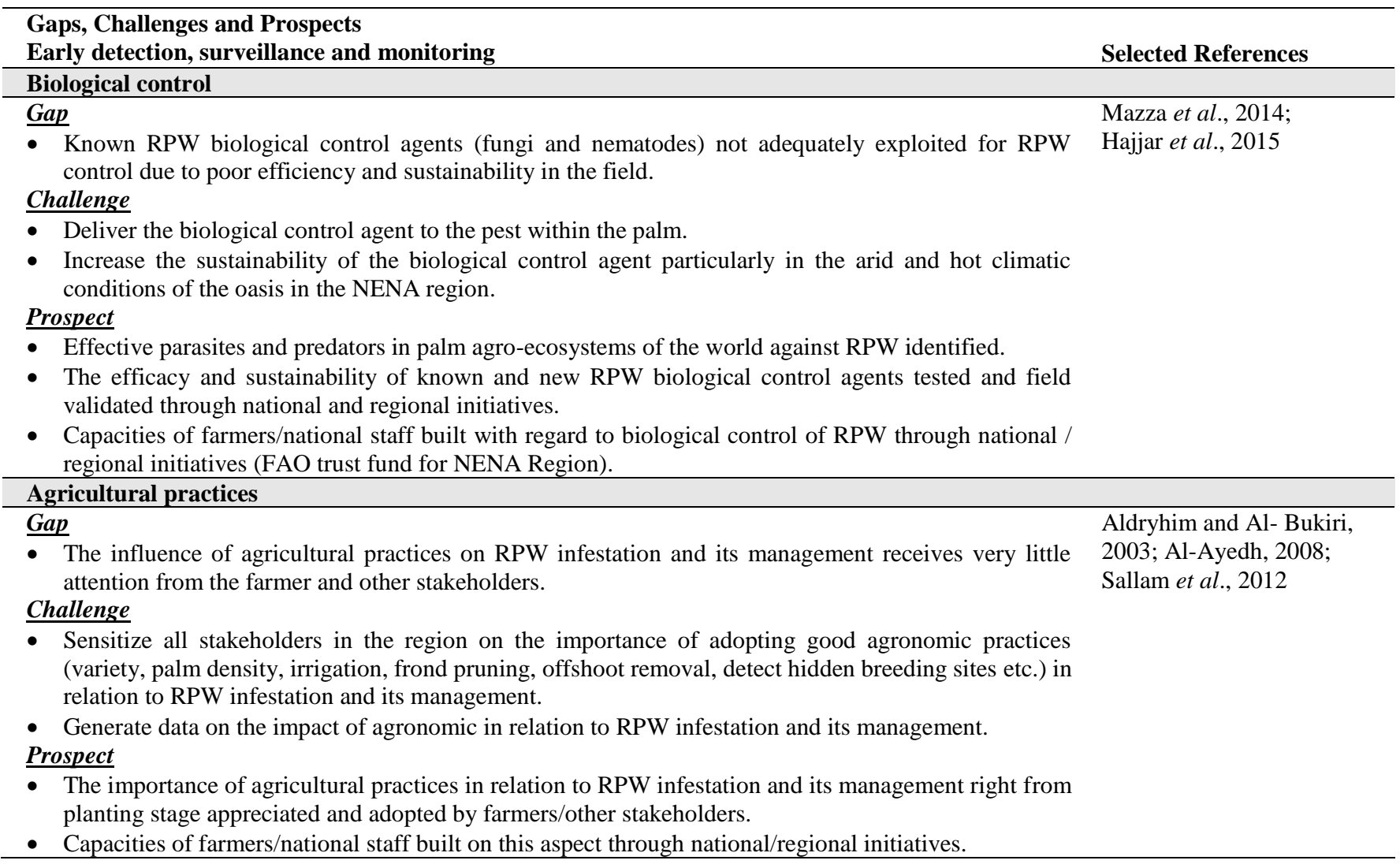

\section{New RPW-IPM Tools}

In recent years, a large number of new RPW-IPM tools (detectors, surveillance drones, pesticides, palm injectors, semiochemicals, biological control agents, palm shredders, micro wave treatment devices, etc.) became available in the market. These IPM tools need proper testing and validation at the national and regional levels so that only field worthy technologies that are not costly and easy to use are made available to the farmers.

\section{Recent FAO Initiatives Against RPW}

During 2018 there have been two major FAO initiatives against RPW that have arisen mainly as an outcome of the "Scientific Consultation and High-Level Meeting on Red Palm Weevil Management" held in Rome during March 2017.

\section{FAO Programme on Red Palm Weevil Eradication}

This project aims at creating a framework for cooperation and coordination of efforts at the regional level for supporting the integrated and sustainable management programs to control RPW; and to reduce its devastating effects on the environment and food security, and socioeconomic impact on rural communities.

The objective of this project, is to support efforts/programs of countries in the NENA region to contain the spread and eradication of the pest. The key outputs of the project, revolve on the governance (policies and regulations in order to support the sustainable management of RPW, including phytosanitary and quarantine management practices for fast eradication of RPW and rational use of pesticides), monitoring (early warning, and risk assessment system of RPW control), scientific research (innovation for long-term solutions), capacity building (for stakeholders, farmers, and improved access to sustainable management practices for RPW) and coordination (RPW control response coordinated across countries and the region).

The program fosters ongoing research on the applicable approaches of biological control and innovative detection and control methods. Research priorities on RPW in the project will be identified on the criteria of innovation, applicability, transferability, field experience, sustainability, simplicity/practicality and user-friendly technologies.

\section{FAO Global RPW management platform}

This project aims to address critical shortcomings in the field for effective monitoring and management of RPW; to systematically collect standard geo-referenced data for which FAO is developing a global RPW monitoring and early warning system. This system consists of a mobile App for data collection in the field and GIS-based online system for data analysis and mapping combined with remote sensing imagery.

In conclusion it can be said that to take RPW control to new level, there is an urgent need to address the gaps and challenges of each of the RPW-IPM components, besides studying the socio-economic impacts and enhance farmer participation in the control program. 


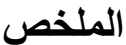

فاليرو، جو رومينو، ميشيل فيري، ثائر ياسين وشوقي الابعي. 2019. لمحة عامة حول الثغرات والتحديات وآفاق إدارة سوسة النخيل الحمراء. مجلة وقاية النبات العربية، 37 (2): 177-170.

برزت سو سة النخيل الحمر اء كآفة رئيسةٍ لأشجار النخيل في النظم البيئية الزراعية المتنوعة حول العالم. اتخذت

سو سة النخيل الحمر اء من جنوب وجنوب شرق آسيا موطناً حيث كانت آفةً رئيسةً لنخيل جوز الهند؛ ومنذ ذلك الحين فقد سجّلت على نخيل التمر في منطقة الشرق

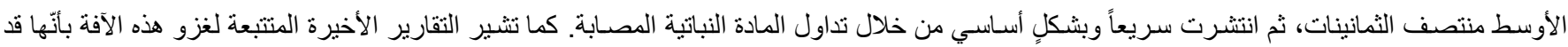
أوجدت لها موطئ قدٍ في منطقة القوقاز حيث تمّ الكثـف عنها في كلٍ من سـوتثـي في روسيا وأبخازيا في جمهورية جورجيا، وكذلك في شـرق أفريقيا (جيبوتي). ومن بين التقنيات الأخرى، فقد طبّقت بر امج المكافحة المتكاملة الحالية لسـوســة النخيل الحمر اء باســتخدام المصــائد الفيرمونية/الطعوم الغذائية ولكنّها لاقت نجاحاً محدوداً. إنّ الثغر ات و التحديات المنضـوية بمجملها تقريباً ضـمن عناصـر هذه الاستر اتيجية (لاسيّما فيما بتعلّق بالكثـف المبكّر للآفة، تطوير وتنفيذ ندابير الصـحة

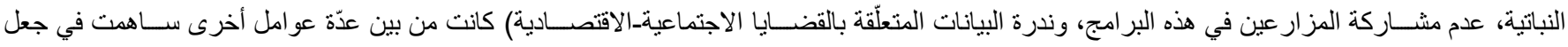

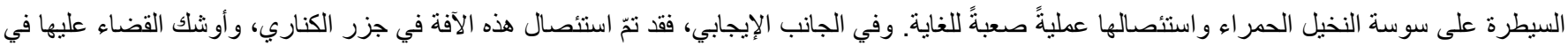

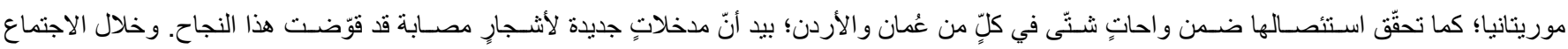
العلمي الرفيع المستوى والذي عقد خلال شهر آذار/مارس من عام 2017 حول إدارة سوسة النخيل الحمر اء، فقد دعت منظمة الأغذية والزر اعة (الفاو) التابعة للأمم

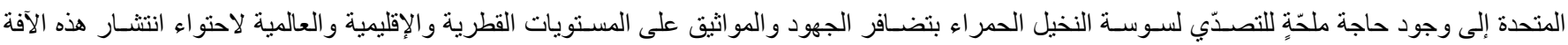

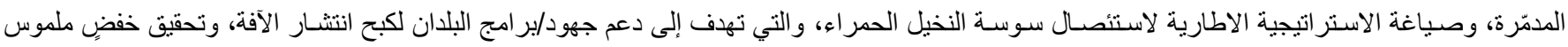
للآفة يفضي لاستئصالها. وقد نتج عن ذلك "برنامج منظمة الفاو حول استئصال سوسة النخيل الحمر اء في منطقة الشرق الأدنى وشمال إفريقيا" لإحكام السيطرة، وتكثيف: المر اقبة/الرصد، البحث العلمي، بناء القدرات، والتنسيق. ويرعى البرنامج الأبحاث الجارية بثـأن المقاربات التطبيقية للمكافحة الحيوية والطر ائق المبتكرة

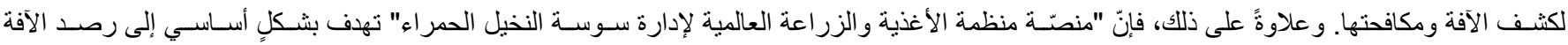

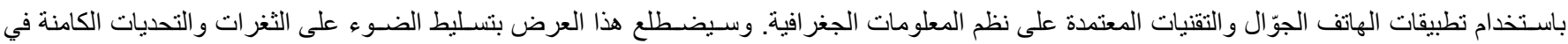
الاستر اتيجية الحالية للمكافحة المتكاملة لسوسـة النخيل الحمر اء مع آفاق تطوير كلّ عنصر مُدرج ضمن هذه الاستر اتيجية؛ وذلك استناداً لمعرفةٍ أوسـع حول الحالة الاجتماعية_الاقتصادية، ومشاركة المزار عين و غير هم من أصحاب المصلحة. كلمات مفتاحية: Rhynchophorus ferrugineus، نطاق الإدارة، إقليمي، عالمي، قيود، رؤية.

\section{References}

Abraham V.A., M. Al-Shuaibi, J.R. Faleiro, R.A. Abouzubairah and P.S.P.V. Vidyasagar. 1998. An integrated approach for the management of red palm weevil Rhynchophorus ferrugineus Oliv.- A key pest of date palm in the Middle East. Sultan Qaboos University Journal for Scientific Research (Agricultural science), 3: 77-83. https://doi.org./10.24200/jams.vol3iss1pp77-83

Abdedaiem, S., N. Nasr and M. Ferry. 2017. Socioeconomic studies and approaches to involve farmers in the fight against red palm weevil (RPW). Presented at the "Scientific Consultation and HighLevel Meeting on Red Palm Weevil Management", organized by FAO and CIHEAM, Italy, 29-31 March, 2017, Rome, Italy.

Al-Dosary, N.M., S. Al-Dobai and J.R. Faleiro. 2016. Review on the Management of Red Palm Weevil Rhynchophorus ferrugineus Olivier in Date Palm Phoenix dactylifera L. Emirates Journal of Food and Agriculture, 28: 34-44.

https://doi.org/10.9755/ejfa.2015-10-897

Aldobai, S. and M. Ferry. 2017. Proposed multidisciplinary and multi-regional strategy for the management of red palm weevil. Presented at the
"Scientific Consultation and High-Level Meeting on Red Palm Weevil Management", organized by FAO and CIHEAM, Italy, 29-31 March, 2017, Rome, Italy.

Al-Ayedh, H. 2008. Evaluation of date palm cultivars for rearing the red date palm weevil, Rhynchophorus ferrugineus (Coleoptera: Curculionidae). Florida Entomologist, 91: 353-358. https://doi.org/10.1653/00154040(2008)91[353:eodpcf]2.0.co;2

Aldawood, A.N., F. Alsagan, H. Altuwariqi, A. Almuteri and K. Rasool. 2013. Red palm weevil chemical treatments on date palms in Saudi Arabia: results of extensive experimentations. Colloque méditerranéen sur les ravageurs des palmiers, Nice, France, 16-18 Janvier, 2013.

Aldryhim, Y. and S. Al- Bukiri. 2003. Effect of irrigation on within - grove distribution of red palm weevil Rhynchophorus ferrugineus. Sultan Qaboos University. Journal of Agricultural and Marine Sciences [JAMS], 8: 47-49. https://doi.org/10.24200/jams.vol8iss1pp47-49

Al-Saroj, S., E. Al-Abdallah, A.M. Al-Shawaf, A.M. AlDandan, I. Al-Abdullah, A. Al-Shagag, Y. AlFehaid, A. Ben Abdallah and J.R. Faleiro. 2017. 
Efficacy of bait free pheromone trap (Electrap ${ }^{\mathrm{TM}}$ ) for management of red palm weevil, Rhynchophorus ferrugineus (Olivier) (Coleoptera: Curculionidae). Pest Management in Horticultural Ecosystems, 23: 55-59.

El-Shafie, H.A.F. and J.R. Faleiro. 2017. Optimizing components of pheromone-baited trap for the management of red palm weevil, Rhynchophorus ferrugineus (Coleoptera: Curculionidae) in date palm agroecosystem. Journal of Plant Diseases and Protection, 124: 279-287 https://doi.org/10.1007/s41348-017-0097-5

FAO. 2017. FAO multi-disciplinary and multi-regional strategy for the management of red palm weevil. http://www.fao.org/3/a-ms665e.pdf (accessed on 15 November, 2018).

Faleiro, J.R. 2006. A review of the issues and management of the red palm weevil Rhynchophorus ferrugineus (Coleoptera: Rhynchophoridae) in coconut and date palm during the last one hundred years. International Journal of Tropical Insect Science, 26:135-154. https://doi.org/10.1079/IJT2006113

Faleiro, J.R., A., Ben Abdullah, M., El-Bellaj, A.M. Al Ajlan and A. Oihabi. 2012. Threat of red palm weevil, Rhynchophorus ferrugineus (Olivier) to date palm plantations in North Africa. Arab Journal of Plant Protection, 30:274-280.

Fleiro, J.R. 2018. Consultancy Report, submitted to FAO, Georgia on completion of a 7-day mission (11-17 February, 2018) to the Republic of Georgia on the control of red palm weevil in Abkhazia during February, 2018. 8pp.

Fajardo, M., X. Rodríguez, C.D. Hernández, L. Barroso, M. Morales, A. González and R. Martín. 2017a. The Canary island success story in eradicating red palm weevil. Presented at the "Scientific Consultation and High-Level Meeting on Red Palm Weevil Management", organized by FAO and CIHEAM, Italy, 29-31 March, 2017, Rome, Italy.

Fajardo, M., J.A. Guerra, L. Barroso, M. Morales and R. Martín. 2017b. Use of GIS (Geographical Information System) for data analysis in a Rhynchophorus ferrugineus eradication program. Presented at the "Scientific Consultation and High-Level Meeting on Red Palm Weevil Management", organized by FAO and CIHEAM, Italy, 29-31 March, 2017, Rome, Italy.

Ferry, M. and S. Gomez. 2014. Assessment of risks and interest of injection techniques in integrated programmes to eradicate the red palm weevil: review and new perspectives. Fruits, 69: 143-157. https://doi.org/10.1051/fruits/2014005

Ferry, M. 2017. Recent advances in insecticide treatments against red palm weevil. Presented at the "Scientific Consultation and High-Level Meeting on Red Palm Weevil Management", organized by FAO and CIHEAM, Italy, 29-31 March, 2017, Rome, Italy.

Ferry, M., S. Aldobai and H. Elkakhy 2018. The state of art of the control of the red palm weevil Presented at the Sixth International Date Palm Conference, 19-21 March, organized by Khalifa International Award for Date Palm and Agricultural Innovation.
Giblin-Davis, R.M., J.R. Faleiro, J.A. Jacas, J.E. Peña, and P.S.P.V. Vidyasagar. 2013. Coleoptera: Biology and management of the red palm weevil, Rhynchophorus ferrugineus. Pages 1-34. In: Potential Invasive Pests of Agricultural Crop Species. J.E. Peña (ed.). CABI Wallingford, UK.

Gomez, S. and M. Ferry. 2002. The red palm weevil in the Mediterranean area, (formerly Principes) Palms, 46: 172-178.

Hajjar, M.J., A.M. Ajlan and M.H. Al-Ahmad. 2015. New approach of Beauveria bassiana to control the red palm weevil (Coleoptera: Curculionidae) by trapping technique. Journal of Economic Entomology,108: 425-432. https://doi.org/10.1093/jee/tou055

Hoddle, M.S., A.H. Al-Abbad, H.A.F. El-Shafie, J.R. Faleiro, A.A. Sallam and C.D. Hoddle. 2013. Assessing the impact of pheromone trapping, pesticide applications, and eradication of infested date palms for Rhynchophorus ferrugineus (Coleoptera: Curculionidae) management in Al Ghowaybah, Saudi Arabia. Crop Protection, 53:152-160. https://doi.org/10.1016/j.cropro.2013.07.010

Mankin, R.W. 2017. Towards user friendly early detection acoustic devices and automated monitoring for red palm weevil management. Presented at the "Scientific Consultation and High-Level Meeting on Red Palm Weevil Management", organized by FAO and CIHEAM, Italy, 29-31 March, 2017, Rome, Italy.

Mazza, G., V. Francardi, S. Simoni, C. Benvenuti, R. Cervo, J.R. Faleiro, E. Llácer, S. Longo, R. Nannelli, E. Tarasco and P.F. Roversi. 2014. An overview on the natural enemies of Rhynchophorus palm weevils, with focus on $R$. ferrugineus. Biological Control, 77: 83-92. https://doi.org/10.1016/j.biocontrol.2014.06.010

Massoud, M.A., A.A. Sallam, J.R. Faleiro and S. AlAbdan. 2012. Geographic information system-based study to ascertain the spatial and temporal spread of red palm weevil Rhynchophorus ferrugineus (Coleoptera: Curculionidae) in date plantations. International Journal of Tropical Insect Science, 32: 108-115. https://doi.org/10.1017/s174275841200015x

Milosavljević, I., H.A.F. El-Shafie, J.R. Faleiro, C.D. Hoddle, M. Lewis and M.S. Hoddle. 2018. Palmageddon: the wasting of ornamental palms by invasive palm weevils, Rhynchophorus spp. Journal of Pest Science, 92: 143-156 https://doi.org/10.1007/s10340-018-1044-3.

Pugliese, M., A.A., Rettori, R. Martinis, K. Al-Rohily and A. Al-Maashi. 2018. Devices to detect red palm weevil infestation on palm species. Precision Agriculture, 19: 1049-1061. https://doi.org/10.1007/s11119-018-9573-6.

Sallam, A.A., H.A.F. El-Shafie and S. Al-Abdan. 2012. Influence of farming practices on infestation by red palm weevil Rhynchophorus ferrugineus (Olivier) in date palm: A case study International Research Journal of Agricultural Science and Soil Science, 2: 370-376. 
Soroker, V., P. Suma, A. La Pergola, V. Navarro-Llopis, S. Vacas, Y. Cohen, Y. Cohen, V. Alchanatis, P. Milonas, D. Kontodimas, O. Golomb, E.Goldshtein, A. M. El Banna and A. Hetzroni. 2017. Detection of red palm weevil infestation. Presented at the "Scientific Consultation and High-Level Meeting on Red Palm Weevil Management", organized by FAO and CIHEAM, Italy, 29-31 March, 2017, Rome, Italy.

Soroker, V., A. Harari and J.R. Faleiro. 2015. The role of semiochemicals in date pest management. In "Sustainable Pest Management In: Date Palm: Current Status and Emerging Challenges. W. Wakil, J.R. Faleiro and T. Miller (eds.). Springer International Publishing. Switzerland. 445 p.
Vacas, S., M. Abad-Paya', J. Primo and V. NavarroLlopis. 2014. Identification of pheromone synergists for Rhynchophorus ferrugineus trapping systems from Phoenix canariensis palm volatiles. Journal of Agricultural and Food Chemistry, 62: 6053-6064. https://doi.org/10.1021/jf502663y

Vidyasagar, P.S.P.V., M. Hagi, R. A. Abozuhairah, O.E. Al-Mohanna, and A.A. Al-Saihati. 2000. Impact of mass pheromone trapping on red palm weevil adult population and infestation level in date palm gardens of Saudi Arabia. Planter, 76: 347-355.

Yu, R. and P. Leung. 2006. Optimal pest management: A reproductive pollutant perspective. International Journal of Pest Management, 52: 3155-166. https://doi.org/10.1080/09670870600774273 